\title{
THE EFFECTS OF LAND USE AND SOIL MANAGEMENT ON THE PHYSICAL PROPERTIES OF AN OXISOL IN SOUTHEAST BRAZIL ${ }^{(1)}$
}

\author{
Getulio de Freitas Seben Junior ${ }^{(2)}$, José Eduardo Corá(3) \& $\operatorname{Rattan~Lal~}^{(4)}$
}

\begin{abstract}
SUMMARY
Soils of the tropics are prone to a decrease in quality after conversion from native forest (FO) to a conventional tillage system (CT). However, the adoption of no-tillage (NT) and complex crop rotations may improve soil structural quality. Thus, the aim of this study was to evaluate the physical properties of an Oxisol under FO, CT, and three summer crop sequences in NT: continuous corn (NTcc), continuous soybean (NTcs), and a soybean/corn rotation (NTscr). Both NT and CT decreased soil organic carbon (SOC) content, SOC stock, water stable aggregates (WSA), geometric mean diameter (GMD), soil total porosity (TP), macroporosity (MA), and the least limiting water range (LLWR). However they increased soil bulk density (BD) and tensile strength (TS) of the aggregates when compared to soil under FO. Soil under NT had higher WSA, GMD, BD, TS and microporosty, but lower TP and MA than soil under CT. Soil under FO did not attain critical values for the LLWR, but the lower limit of the LLWR in soils under CT and NT was resistance to penetration (RP) for all values of $B D$, while the upper limit of field capacity was air-filled porosity for BD values greater than 1.46 (CT), 1.40 (NTscr), 1.42 (NTcc), and 1.41 (NTes) $\mathrm{kg} \mathrm{dm}^{-3}$. Soil under NTcc and NTes decreased RP even with the increase in BD because of the formation of biopores. Furthermore, higher critical BD was verified under NTcc $\left(1.62 \mathrm{~kg} \mathrm{dm}^{-3}\right)$ and NTcs $\left(1.57 \mathrm{~kg} \mathrm{dm}^{-3}\right)$ compared to NTscr and CT $\left(1.53 \mathrm{~kg} \mathrm{dm}^{-3}\right)$.
\end{abstract}

Index terms: no-tillage, soil organic carbon, soil aggregate, bulk density, tropical soil, Cerrado.

(1) Excerpt from the Doctoral Thesis of the first author. Received on June 6, 2013 and approved on April 8, 2014.

(2) Adjunct Professor at Universidade do Estado de Mato Grosso - UNEMAT, Campus of Alta Floresta. Av. Perimetral Rogério Silva, s/n, Jardim Flamboyant, CEP 78580 Alta Floresta (MT). E-mail: getulioseben@unemat.br

(3) Associate Professor of Soil Science Department, São Paulo State University - UNESP, Campus of Jaboticabal. Via de Acesso Prof. Paulo Donato Castellane, s/n. CEP 14884-900 Jaboticabal (SP) CNPq Researcher. E-mail: cora@fcav.unesp.br

(4) Professor Emeritus of The Ohio State University, School of Environment and Natural Resources. 2021 Coffey Rd., Columbus, OH 43210, USA. E-mail: lal.1@osu.edu 


\title{
RESUMO: SISTEMAS DE USO E MANEJO DO SOLO SOBRE OS ATRIBUTOS FÍSICOS DE UM LATOSSOLO NO SUDESTE DO BRASIL
}

\begin{abstract}
A qualidade física dos solos sob clima tropical está sujeita à degradação, após a conversão de mata nativa em sistema de cultivo convencional (SCC). Entretanto, a adoção do sistema de semeadura direta $(S S D)$ com a rotação de culturas proporciona melhorias à qualidade do solo. Assim, o objetivo deste estudo foi avaliar os atributos físicos de um Latossolo Vermelho sob mata nativa, SCC e SSD, envolvendo sequências de culturas de verão: Milho em Monocultura (SSD-MM), Soja em Monocultura (SSD-SM) e rotação soja / milho (SSD-RSM). As sequências de culturas sob SSD e SCC proporcionaram reduções no teor de carbono orgânico, no estoque de carbono, no índice de estabilidade de agregados (IEA), no diâmetro médio ponderado (DMP), na porosidade total (PT), na macroporosidade (MP) e no intervalo hídrico ótimo (IHO); no entanto, aumentaram a densidade do solo (DS) e a resistência tênsil dos agregados (RT), em comparação à mata nativa. O SSD proporcionou ao solo maiores valores de IEA, DMP, DS, RT e microporosidade e menores valores de PT e MP, em comparação ao SCC. O limite inferior do IHO no solo sob SSD e SCC foi a resistência à penetração para todos os valores de DS, enquanto o limite superior foi a porosidade de aeração para valores de DS

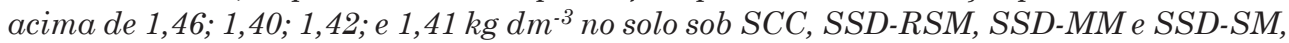
respectivamente. No solo sob SSD-MM e SSD-SM, a redução da resistência à penetração com o aumento da DS pode ser atribuida à formação de bioporos. Além disso, a maior densidade crítica foi verificada sob SSD-MM $\left(1,62 \mathrm{~kg} \mathrm{dm}^{-3}\right)$ e $S S D-S M\left(1.57 \mathrm{~kg} \mathrm{dm}^{-3}\right)$ quando comparada ao SSD-RSM e SCC $\left(1.53 \mathrm{~kg} \mathrm{dm}^{-3}\right)$.
\end{abstract}

Termos de indexação: plantio direto, carbono orgânico do solo, agregado do solo, densidade do solo, solo tropical, Cerrado.

\section{INTRODUCTION}

Soils of the tropics are prone to degradation upon conversion of native forest (FO) to cropland systems (Houghton et al., 1991) through an increase in the intensity of soil disturbance by conventional tillage, which breaks up soil aggregates and exposes soil organic carbon (SOC) to decomposition (Lal, 1976). The Cerrado (tropical savanna) is the largest biome in the Brazilian tropical region and covers 200 million hectares (Mha), 70 Mha of which have been converted to cropland (Goedert, 1989). Soils under the Cerrado represent $25 \%$ of the agricultural land in Brazil, and $4 \%$ of the world's tropical soils, which can be a significant C sink if the no-tillage (NT) system is widely adopted (Bayer et al., 2006).

Depletion of SOC by conversion of primary FO into cropland is the second largest $\mathrm{C}$ source of humaninduced emissions (Don et al., 2011). The magnitude of SOC depletion in soils of tropical agroecosystems may be as much as $75 \%$ or more (Lal, 2004). Reduction of SOC below the critical level exacerbates degradation of soil structure, increases bulk density (BD), decreases aggregation, reduces soil moisture storage, decreases aeration (Fageria, 2012), and adversely impacts grain yield (Fuentes et al., 2009). Loss of SOC can be reversed by using less intensive cultivation practices, and by changing from monoculture to complex rotations (West \& Post, 2002). In addition, NT restores soil structure and increases SOC by an average of $0.43 \mathrm{Mg} \mathrm{ha}^{-1} \mathrm{yr}^{-1}$ at the $0-10 \mathrm{~cm}$ depth in tropical soils (Six et al., 2002).

Conversion of a conventional tillage system (CT) to NT may increase SOC by $57 \pm 14 \mathrm{~g} \mathrm{~m}^{-2} \mathrm{yr}^{-1} \mathrm{C}$ (West
\& Post, 2002) and also enhance SOC stabilization and crop yield (Bhattacharyya et al., 2012), improve aggregation (Albuquerque et al., 1995), increase soil water reserves (Peres et al., 2010), and reduce the risks of initial compaction under NT by decreasing soil disturbance (Carter et al., 1999).

Adoption of NT in conjunction with a complex crop rotation from monoculture can increase SOC by $20 \pm$ $12 \mathrm{~g} \mathrm{C} \mathrm{m}^{-2} \mathrm{yr}^{-1}$ (West \& Post, 2002) and it improves soil aggregation by the addition of crop residues on the soil surface or in the soil profile by the root system depending on the crop species and climatic conditions (Martins et al., 2012; Sá et al., 2013). Fabaceae and poaceae are the families most used for crop rotation in the NT system. Fabaceae may increase soil $\mathrm{C}$ by $0.88 \mathrm{Mg} \mathrm{yr}{ }^{-1} \mathrm{C}$ due to the close $\mathrm{C}: \mathrm{N}$ ratio of the crop biomass, which favors fast decomposition, and due to the association between crop roots and microorganisms (Zotarelli et al., 2007; Boddey et al., 2010; Conceição et al., 2013). In contrast, poaceae produce a greater quantity of root biomass than fabaceae Wide distribution of exudates and enzymes from both increase soil aggregation and add more than $0.71 \mathrm{Mg} \mathrm{yr}^{-1}$ of $\mathrm{C}$. (Martins et al., 2012).

Management-induced changes in soil can be evaluated by assessing structural properties, such as the least limiting water range (LLWR) (Silva et al., 1994). The LLWR considers the soil moisture range where no limitations to plant growth are expected when considering soil air-filled porosity (AP), resistance to penetration $(\mathrm{RP})$, and plant available water capacity (AWC) between the field capacity (FC) and permanent wilting point (PWP) (Reichert et al., 2009). In addition to the LLWR, other properties may be used to evaluate 
soil structural quality affected by land use and soil management, such as SOC content (Tivet et al., 2012), BD (Viana et al., 2011), SOC stock (Zotarelli et al., 2012), water stable aggregates (WSA) (Martins et al., 2012), geometric mean diameter (GMD) (Seben Júnior et al., 2011), RP (Silva \& Kay, 2004), tensile strength (TS) (Tormena et al., 2008), total porosity (TP), microporosity (MI), and macroporosity (MA) (Wendling et al., 2012).

It is important to evaluate the impacts of intensive management systems on soil structure, such as soil under NT in comparison with soil under FO. Continuously high rainfall and temperature may exacerbate SOC depletion, soil structure decline, and reduction in agronomic production. Thus, the present study was conducted to test the hypothesis that conversion of FO to cropland systems decreases soil structural quality, and that the adoption of NT can reduce the impacts caused by intensive soil disturbance under CT and improve soil physical quality. Therefore, the specific objective of the present study was to evaluate the impacts of CT, NT, and FO on soil physical quality.

\section{MATERIALS AND METHODS}

The experimental area was located in Jaboticabal, SP, Brazil ( $\left.21^{\circ} 15^{\prime} 22^{\prime \prime} \mathrm{S}, 48^{\circ} 18^{\prime} 58^{\prime \prime} \mathrm{W}\right)$. Climatologically, the area belongs to the tropical/megathermal zone, or Köppen's Aw (a tropical climate with a dry winter and an average temperature of the coldest month higher than $\left.18{ }^{\circ} \mathrm{C}\right)$. The mean annual rainfall of the region (1971-2011) is $1,417 \mathrm{~mm}$, with an annual distribution that peaks during October to March, and a relatively dry season from April to September (Figure 1). The soil under study was a Latossolo Vermelho (Oxisol) with a moderate hypoferric clay texture, and gentle slopes (Embrapa, 2006).

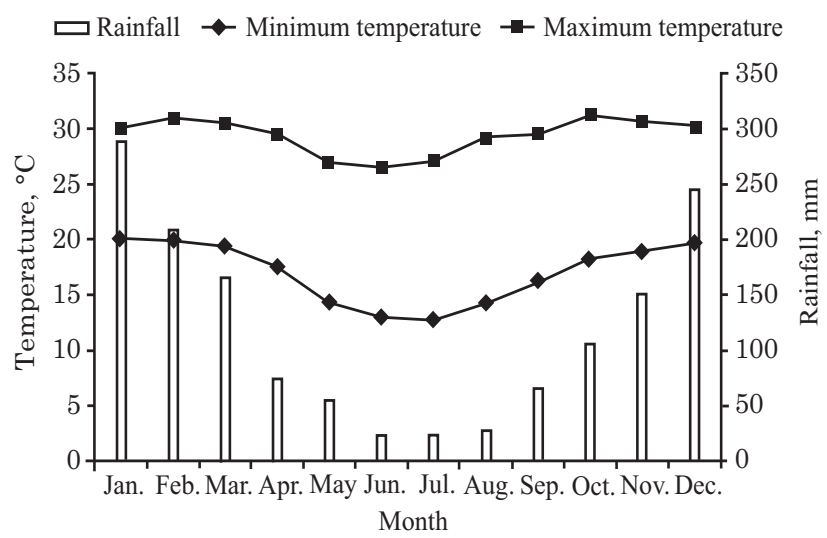

Figure 1. Monthly average for maximum and minimum temperatures and rainfall in the experimental area (1971-2010).
Soil use and management systems were FO, CT, and NT. The FO is a fragment of Atlantic forest under climax vegetation. The CT was established after deforestation and was used to grow corn (Zea mays L.) or soybean (Glycine max (L.) Merrill) in the spring/ summer and kept fallow during autumn/winter for more than 35 years. In September 2002, part of the area under CT was converted to NT.

Within NT, three summer crop sequences were established: continuous corn (NTcc), continuous soybean (NTcs), and soybean/corn rotation (NTscr). During the autumn/winter, for each summer crop sequence, the following seven winter crops were grown: corn, sunflower (Helianthus annuus L.), oilseed radish (Raphanus sativus L.), pearl millet (Pennisetum americanum (L.) Leeke), pigeon pea (Cajanus cajan (L.) Millsp), grain sorghum (Sorghum bicolor (L.) Moench) and sunn hemp (Crotalaria juncea L.), as shown in figure 2.

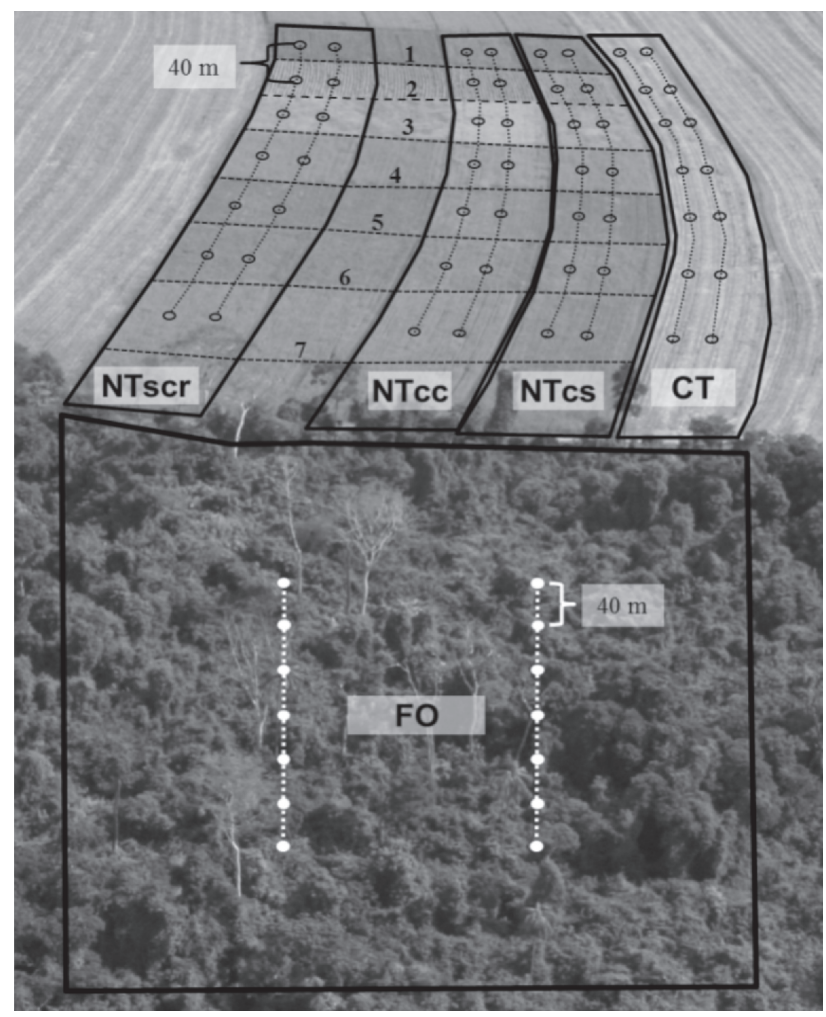

Figure 2. Aerial view showing the area of study under use and management systems as follows: Notillage system planted to summer crops soybean/corn rotation (NTscr), continuous corn (NTcc), and continuous soybean (NTcs); conventional tillage system (CT); and native forest (FO). Between summer crops in no-till, there are seven winter crops: corn, sunflower, oilseed radish, pearl millet, pigeon pea, grain sorghum, and sunn hemp. Within each treatment, the dotted line represents two transects with 14 points where soil samples were collected, $40 \mathrm{~m}$ distant from one another. 
Soil samples were taken from the $0-10 \mathrm{~cm}$ depth within each land use and management treatment in October, 2011 at 14 locations divided into two paired transects (Figure 2). Within each location, grab samples were collected as follows: two soil blocks (of $10 \times 15 \times 20 \mathrm{~cm}$ height, width, and length, respectively), and 10 disturbed soil samples using a straight shovel. In addition, two undisturbed soil cores (5.0 $\mathrm{cm}$ diameter by $5.0 \mathrm{~cm}$ depth) were collected in each location for a total of 28 core samples for each land use and management system.

Soil blocks were packed so as to preserve soil structure and moisture content. For each soil block, 40 aggregates of 12.5-19.0 mm diameter were obtained to determine the TS (Watts \& Dexter, 1998). Aggregates were oven dried at $105^{\circ} \mathrm{C}$ for $24 \mathrm{~h}$, placed in a desiccator to attain ambient temperature, weighed, and subjected to the TS test by a digital dynamometer, coupled to a load cell of $20 \mathrm{kgf}$ capacity and adjusted to record the maximum compressive force needed to break the aggregate.

The composite disturbed soil samples were broken up and sieved manually at the antecedent moisture content in the field. Then, the composite samples were divided into three parts. The first part was used to separate aggregates from 4.0 to $6.3 \mathrm{~mm}$. The second part was used to separate aggregates from 1.0 to $2.0 \mathrm{~mm}$. These aggregates were air-dried for $48 \mathrm{~h}$. Larger aggregates were used to determine the GMD, and smaller aggregates were used to determine the WSA, both according to Nimmo \& Perkins (2002). The third part was used to determine the SOC content following the method of Yeomans \& Bremner (1988).

The GMD was determined using $30 \mathrm{~g}$ of air-dried aggregates transferred to a nest of sieves of 4.00, 2.00, $1.00,0.50,0.25$, and $0.125 \mathrm{~mm}$ mesh sizes. The nest of sieves with the aggregates was directly immersed (without pre-wetting) in water in an apparatus for vertical oscillation (Yoder, 1936) for $15 \mathrm{~min}$, adjusted to 31 cycles $\mathrm{min}^{-1}$, with oscillation amplitude of $35 \mathrm{~mm}$. For determining the WSA, $10 \mathrm{~g}$ of air-dried aggregates was transferred to a sieve with a $0.25 \mathrm{~mm}$ mesh in the apparatus for vertical oscillation for 3 min, adjusted to 35 cycles min $^{-1}$, with an oscillation amplitude of $13 \mathrm{~mm}$. In addition, correction was made for the primary particles and gravels (Kemper \& Rosenau, 1986).

The LLWR was determined using four replications for each matric potential. Total core samples (28 cores $\times 5$ soil use and management systems) were divided into seven groups of 20 samples and saturated for $48 \mathrm{~h}$. Cores from each group were used to determine soil water retention at seven matric potentials: -0.006, -0.01 MPa (using a tension table [Romano et al., 2002]), and $-0.033,-0.06,-0.1,-0.3$, and $-1.5 \mathrm{MPa}$ (using pressure plate extractors [Dane \& Hopmans, 2002]). RP was obtained in each core at every matric potential using a penetrometer equipped with a linear actuator and a load cell of $20 \mathrm{~kg}$, operated at a constant speed of $1.76 \mathrm{~mm} \mathrm{~s}^{-1}$, and coupled to a computer for data acquisition (Figueiredo et al., 2011). The penetrometer cone had an angle of $30^{\circ}$ and base diameter of $3.91 \mathrm{~mm}$. These data were used to calculate the LLWR following the method suggested by Silva et al. (1994). We considered the limits for determination of the LLWR as follows: FC at $-0.01 \mathrm{MPa}$ (Reichardt, 1988), PWP at -1.5 MPa (Savage et al., 1996), RP limit for plant growth of 3.5 MPa (Tormena et al., 2007), and the limit for AP of $10 \%$ (Grable \& Siemer, 1968). The empirical parameters used to adjust the equations to obtain the LLWR and the critical BD were obtained using a simplified algorithm developed in Excel ${ }^{\circledR}$ software by Leão \& Silva (2004). The TP, MI, and MA (Flint \& Flint, 2002), and BD (Grossman $\&$ Reinsch, 2002) were obtained in each soil core.

The SOC stock was calculated from the SOC content and BD. The SOC stock was corrected for the equivalent soil mass method (Ellert \& Bettany, 1995), using the SOC content under FO as the baseline.

Each soil use and management system was considered as a randomized sample with a population equal to seven. The data were subjected to analysis of variance ( $\mathrm{F}$ test) with $1 \%$ probability, and the means were compared by the Tukey test $(\alpha<0.01 \%)$. The data initially exhibited normal distribution by the Shapiro-Wilk test and homoscedasticity of variances by the Levene test, both significant at $5 \%$. These analyses were performed using the SAS statistical package (SAS, 2001).

\section{RESULTS AND DISCUSSION}

Both CT and NT systems decreased SOC content and SOC stock in comparison to those under FO (Table 1). Conversion of FO to cropland systems ruptured aggregates by soil disturbance and exposed the SOC to degradation by oxidation, mineralization, or by microorganisms. An increase in access of SOC to microorganisms can enhance its decomposition (Dungait et al., 2012). Relatively higher input of biomass-C to soil under FO is attributed to continuous input and decomposition of litterfall and roots, which is physically protected against microbial degradation within aggregates (Kleber et al., 2011). The lack of any significant difference between NT and CT for SOC content may be attributed to the short time since adoption of NT because SOC rates are stabilized within 5 to 20 years after conversion of CT to NT (Lal, 2004). Furthermore, SOC content may plateau after 25 to 50 years. or when the soil sink capacity is filled (West \& Post, 2002; Lal, 2004).

Rates of SOC sequestration upon conversion of CT to NT (NTscr, NTcc, and NTcs) were 0.03 $\mathrm{Mg} \mathrm{ha}{ }^{-1} \mathrm{yr}^{-1} \mathrm{C}$. Soils of the tropics, because of severe weathering, may have high $\mathrm{C}$ sink capacity, but the rate of SOC sequestration may be low (Lal, 2004). In 
comparison, higher rates of SOC sequestration were reported by Bayer et al. (2006), who observed an increase in SOC stock $(0-20 \mathrm{~cm})$ under NT of 0.30 $\mathrm{Mg} \mathrm{ha}^{-1} \mathrm{yr}^{-1}$ compared to CT in a sandy clay loam Oxisol and $0.60 \mathrm{Mg} \mathrm{ha}^{-1} \mathrm{yr}^{-1}$ in a CT clayey Oxisol, due to a lower rate of organic matter decomposition when soils are undisturbed. In contrast, Roscoe \& Buurman (2003) reported that NT reduced SOC compared to soil under CT (-0.03 $\left.\mathrm{Mg} \mathrm{ha}^{-1} \mathrm{yr}^{-1}\right)$ after 30 years because of soils with high clay and $\mathrm{Fe}+\mathrm{Al}$ oxi-hydroxide contents, and to a sufficient $\mathrm{C}$ supply by the corn.

Table 1. Soil organic carbon content, soil organic carbon stock, water stable aggregates, geometric mean diameter, and soil bulk density evaluated in an Oxisol under native forest (FO); under no-tillage with soybean/corn rotation (NTscr), continuous corn (NTcc), and continuous soybean (NTcs); and under a conventional tillage system (CT)

\begin{tabular}{|c|c|c|c|c|c|}
\hline System & Minimum & Maximum & Average & $\mathrm{SD}^{(1)}$ & $\mathrm{CV}$ \\
\hline & & & & & $\%$ \\
\hline \multicolumn{6}{|c|}{ Soil organic carbon $\left(\mathrm{g} \mathrm{kg}^{-1}\right)$} \\
\hline FO & 29.58 & 30.74 & $30.24 \mathrm{a}$ & 0.40 & 1.3 \\
\hline NTscr & 11.56 & 13.19 & $12.20 \mathrm{~b}$ & 0.54 & 4.4 \\
\hline NTcc & 11.90 & 12.71 & $12.22 \mathrm{~b}$ & 0.25 & 2.0 \\
\hline NTcs & 11.48 & 12.89 & $12.19 \mathrm{~b}$ & 0.55 & 4.5 \\
\hline $\mathrm{CT}$ & 10.44 & 13.34 & $11.80 \mathrm{~b}$ & 1.22 & 10.3 \\
\hline $\mathrm{F}$ test & \multicolumn{5}{|c|}{$10.00^{*}$} \\
\hline \multirow[t]{2}{*}{ CV (\%) } & \multicolumn{5}{|c|}{4.3} \\
\hline & \multicolumn{5}{|c|}{ Soil organic carbon stock $\left(\mathrm{Mg} \mathrm{ha}^{-1}\right)$} \\
\hline $\mathrm{FO}$ & 24.92 & 31.37 & $28.16 \mathrm{a}$ & 2.56 & 9.1 \\
\hline NTscr & 10.64 & 12.13 & $11.23 \mathrm{~b}$ & 0.50 & 4.4 \\
\hline NTcc & 10.94 & 11.69 & $11.25 \mathrm{~b}$ & 0.23 & 2.0 \\
\hline NTcs & 10.56 & 11.86 & $11.22 \mathrm{~b}$ & 0.50 & 4.5 \\
\hline $\mathrm{CT}$ & 9.29 & 13.87 & $10.98 \mathrm{~b}$ & 1.46 & 13.3 \\
\hline F test & & & $21.91^{*}$ & & \\
\hline \multirow[t]{2}{*}{ CV (\%) } & & & 9.3 & & \\
\hline & \multicolumn{5}{|c|}{ Water stable aggregate (\%) } \\
\hline FO & 97.93 & 99.35 & $98.75 \mathrm{a}$ & 0.52 & 0.5 \\
\hline NTscr & 68.65 & 78.09 & $72.69 \mathrm{~b}$ & 3.41 & 4.7 \\
\hline NTcc & 68.64 & 80.15 & $73.89 \mathrm{~b}$ & 4.33 & 5.9 \\
\hline NTcs & 67.53 & 76.80 & $72.47 \mathrm{~b}$ & 4.22 & 5.8 \\
\hline $\mathrm{CT}$ & 49.30 & 62.27 & $56.84 \mathrm{c}$ & 4.22 & 7.4 \\
\hline $\mathrm{F}$ test & & & $11.97^{*}$ & & \\
\hline \multirow[t]{2}{*}{ CV (\%) } & & & 4.9 & & \\
\hline & \multicolumn{5}{|c|}{ Geometric mean diameter $(\mathrm{mm})$} \\
\hline $\mathrm{FO}$ & 3.90 & 4.69 & $4.66 \mathrm{a}$ & 0.02 & 0.4 \\
\hline NTscr & 2.84 & 3.57 & $3.22 \mathrm{~b}$ & 0.28 & 8.7 \\
\hline NTcc & 2.92 & 3.48 & $3.17 \mathrm{~b}$ & 0.17 & 5.3 \\
\hline NTcs & 2.65 & 3.31 & $3.05 \mathrm{~b}$ & 0.25 & 8.1 \\
\hline $\mathrm{CT}$ & 2.19 & 3.21 & $2.76 \mathrm{c}$ & 0.36 & 13.0 \\
\hline $\mathrm{F}$ test & & & $22.56^{*}$ & & \\
\hline \multirow[t]{2}{*}{ CV (\%) } & & & 14.6 & & \\
\hline & \multicolumn{5}{|c|}{ Soil bulk density $\left(\mathrm{kg} \mathrm{dm}^{-3}\right)$} \\
\hline FO & 0.83 & 1.04 & $0.93 \mathrm{c}$ & 0.09 & 9.5 \\
\hline NTscr & 1.40 & 1.51 & $1.45 \mathrm{a}$ & 0.04 & 2.5 \\
\hline NTcc & 1.40 & 1.53 & $1.46 \mathrm{a}$ & 0.04 & 2.9 \\
\hline NTcs & 1.40 & 1.48 & $1.45 \mathrm{a}$ & 0.02 & 1.6 \\
\hline $\mathrm{CT}$ & 1.13 & 1.48 & $1.30 \mathrm{~b}$ & 0.13 & 10.0 \\
\hline $\mathrm{F}$ test & & & $62.17^{*}$ & & \\
\hline $\mathrm{CV}(\%)$ & & & 5.7 & & \\
\hline
\end{tabular}

(1) SD: Standart Deviation. Values followed by the same lowercase letters in the same column are significantly different by the Tukey test $(\mathrm{p}<0.01) ;{ }^{*} \mathrm{p}<0.01$. 
Soil aggregation decreased with an increase in the intensity of soil disturbance in the following order: FO $>$ NTscr $=$ NTcc $=$ NTcs $>$ CT $($ Table 1$)$. These results indicate the importance of reducing soil disturbance, applying crop residues on the soil surface, and adopting crop rotations. Although there were no differences in SOC content among treatments, a higher aggregation under NT (NTscr, NTcc, and NTcs) in comparison to CT may be attributed to the root system of species used in crop rotation compared to the fallow period in soil under CT. Vezzani \& Mielniczuk (2011) observed higher aggregation in soil under Pangola grass (Digitaria decumbens) + corn and oat (Avena strigosa) + corn compared to that under CT, which exhibited lower SOC stock. The authors attributed the results to the specific properties of the root system in improving soil aggregation. Vezzani \& Mielniczuk (2011) also observed that a complex rotation in NT of oat + vetch (Vicia sativa) and corn + cowpea beans (Vigna unguiculata) enhanced SOC and aggregation, approaching the values of those under FO.

Soil BD and TS were in the order $\mathrm{FO}<\mathrm{CT}<\mathrm{NT}$ scr (Tables 1 and 2). These properties under NTcc and NTcs did not differ from those under NTscr and CT; however, there were higher values of $\mathrm{BD}$ and TS than these values under FO. High values of TS in soil under NT may indicate a favorable seedbed with bigger aggregates, in contrast to a soil with a large size range (Tormena et al., 2008). Conversely, the low TS observed in soil under FO may be attributed to smaller aggregates with higher TS which composing bigger aggregates, with lower TS (Imhoff et al., 2002).

A soil under short-term NT is expected to have a higher BD in the surface layer (Tormena et al., 2002) because of machine traffic and absence of soil disturbance (Tormena et al., 1998). A higher BD in soil under NT in comparison to CT and FO was also reported by Calonego et al. (2012), who attributed the trend in soil properties under FO to a lack of soil management, high SOC content with low specific weight, and high natural porosity of SOM humified in an undisturbed soil. Tormena et al. (2008) reported that the quality of an Oxisol decreased in proportion to intensification of soil use $(\mathrm{FO}<$ fallow $<\mathrm{CT}$ ). However, soil under long-term NT tends to have a low $\mathrm{BD}$ because of bioturbation and the impact of diverse species on complex crop rotations. Lanzanova et al. (2010) observed that 16 years after adoption of NT, crop rotation and cover crops reduced BD and increased TP and MA in comparison to these features for bare/unprotected soil.

In contrast to the trends in TS and $\mathrm{BD}$, both TP and MA increased from NT (NTscr, NTcc, and NTcs) $<\mathrm{CT}<\mathrm{FO}$ (Table 2). Probably, the increase of BD under NT and the decrease of TP and MA are due to the reorientation of mineral particles. However, an increase in SOC and root system biopores of the species used in crop rotation may reverse the trend over the long term. Biopores are necessary to sustain proper pore functions and the role of soil mechanical properties in continuous use of NT over a long time horizon (Reichert et al., 2009). The positive effect of SOC content in enhancing soil quality was also reported for soils of Queensland, Australia by So et al. (2009). The authors observed that soil under NT for 14 years had higher MA, saturated hydraulic conductivity, water infiltration rate, plant AWC, water use efficiency, and crop yields while it had lower BD, dispersible clay, and water run-off than soil under CT.

The results of the present study showed higher TP and MA in soil under CT compared to NT, due to soil disturbance in the surface layer. However, MA under CT was substantially reduced from the surface $(0-10 \mathrm{~cm})$ to sub-soil layers, though it was enhanced in the soil profile under NT (Cássaro et al., 2011). According to Cavalieri et al. (2009), soil pore connectivity is more important than the magnitude of TP and MA for soils under long-term NT. These trends are in accord with the observation that most of the pores in the sub-soil do not conduct water and air. In the present study, MA volume, observed in soil under NTcc and NTcs, seems not to have restricted plant development although it was lower than $0.10 \mathrm{~m}^{3} \mathrm{~m}^{-3}$, a value mentioned by Silva et al. (1994) as critical to satisfactory plant growth. Sometimes, critical values of MA are not restrictive to root development and crop yield in NT because of the tolerance of the species (Reichert et al., 2009). Jemai et al. (2013) also observed that soil under CT had higher MA than that under NT in the 0-10 cm layer. However, seven years of NT improved MA more than three years of NT, probably, according to the authors, by transformation of a part of fine pores into macropores.

In the present study, soil under NT had higher MI than soil under CT but lower than soil under FO (Table 2). Increase in BD under NT, due to absence of soil disturbance, reduced MA but increased MI by reduction of pore diameter in comparison to $\mathrm{BD}$ under CT. Reichert et al. (2009) reported that an increase in $\mathrm{BD}$ is not necessarily critical to crop development because of the increase in soil water storage within a specific range of BD. Increase in MI under NT plus the strong natural structure inherent in soils of the tropics may accentuate soil water retention during periods of the year with low precipitation (van den Berg et al., 1997).

Soil under CT had the highest range of variation (difference between maximum and minimum values) in SOC content, SOC stock, WSA, GMD, BD, and TS, and the highest CV for SOC content, WSA, GMD, $\mathrm{BD}$, and TS (Tables 1 and 2). Lower variability in soil properties under NT and FO compared to CT may be attributed to homogeneous distribution of plant residues (NT) or litterfall (FO) on the soil surface, as well as by low soil disturbance, which 
are conducive to development of soil structure in the topsoil.

The LLWR is represented by the shaded area in figure 3. Neither soil AP or RP under FO were restrictive to root growth for any values of BD since the upper limit was FC and the lower limit was PWP. Little or no soil disturbance enhanced soil aggregation, leading to a large distribution of pore size, which contributed to water retention. Thus, in the present study, there were no structural limitations to plant growth for the range of AWC (between FC and PWP). Araújo et al. (2004) also reported no restriction of AP and RP to root growth for any values of BD under FO.
For all land management systems (CT and NT NTscr, NTcc, and NTcs), RP was the lower limit of the LLWR. In soil under CT and NTscr, RP was positively correlated with $\mathrm{BD}$, leading to a decrease in the LLWR. In contrast, negative correlation between RP and BD was observed under NTcc and NTcs, and the LLWR expanded with an increase in $\mathrm{BD}$, probably due to the formation and, or, presence of continuous biopores in the soil surface layer. Formation of biopores may reduce the adverse effects of a high $\mathrm{RP}$ and reduce its negative influence on root growth and crop yield. The RP value of 3.5 MPa may not be restrictive to root system growth in soil under NT because of the abundance of biopores (Ehlers et

Table 2. Tensile strength, total porosity, microporosity, and macroporosity evaluated in an Oxisol under native forest (FO), under no-tillage with soybean/corn rotation (NTscr), continuous corn (NTcc), and continuous soybean (NTcs); and under a conventional tillage system (CT)

\begin{tabular}{|c|c|c|c|c|c|}
\hline System & Minimum & Maximum & Average & $\mathrm{SD}^{(1)}$ & $\mathrm{CV}$ \\
\hline & & & & & $\%$ \\
\hline & \multicolumn{5}{|c|}{ Tensile strength $(\mathrm{kPa})$} \\
\hline FO & 14.91 & 35.01 & $24.59 \mathrm{c}$ & 6.31 & 25.6 \\
\hline NTscr & 38.19 & 56.84 & $46.71 \mathrm{a}$ & 6.30 & 13.5 \\
\hline NTcc & 35.27 & 48.18 & $41.50 \mathrm{ab}$ & 4.33 & 10.4 \\
\hline NTcs & 32.92 & 44.93 & $38.56 \mathrm{ab}$ & 4.34 & 11.2 \\
\hline $\mathrm{CT}$ & 19.12 & 57.54 & $34.01 \mathrm{bc}$ & 11.56 & 34.0 \\
\hline $\mathrm{F}$ test & & & $9.78^{*}$ & & \\
\hline \multirow[t]{2}{*}{$\mathrm{CV}$} & & & 19.1 & & \\
\hline & \multicolumn{5}{|c|}{ Total porosity (\%) } \\
\hline FO & 66.48 & 68.96 & $67.53 \mathrm{a}$ & 0.89 & 1.3 \\
\hline NTscr & 42.46 & 51.70 & $47.21 \mathrm{c}$ & 2.73 & 5.8 \\
\hline NTcc & 42.72 & 51.63 & $45.70 \mathrm{c}$ & 3.15 & 6.9 \\
\hline NTcs & 45.85 & 50.16 & $48.03 \mathrm{c}$ & 1.53 & 3.2 \\
\hline $\mathrm{CT}$ & 52.09 & 55.53 & $53.59 \mathrm{~b}$ & 1.29 & 2.4 \\
\hline $\mathrm{F}$ test & & & $12.66^{*}$ & & \\
\hline \multirow[t]{2}{*}{$\mathrm{CV}$} & & & 4.0 & & \\
\hline & \multicolumn{5}{|c|}{ Microporosity (\%) } \\
\hline FO & 37.26 & 39.44 & $38.73 \mathrm{a}$ & 0.75 & 1.9 \\
\hline NTscr & 35.09 & 38.97 & $36.88 \mathrm{a}$ & 1.29 & 3.5 \\
\hline NTcc & 36.42 & 41.01 & $38.62 \mathrm{a}$ & 1.83 & 4.7 \\
\hline NTcs & 36.02 & 44.07 & $39.23 \mathrm{a}$ & 2.55 & 6.5 \\
\hline $\mathrm{CT}$ & 32.35 & 35.59 & $34.05 \mathrm{~b}$ & 1.04 & 3.0 \\
\hline$F$ test & & & $12.00^{*}$ & & \\
\hline \multirow[t]{2}{*}{$\mathrm{CV}$} & & & 4.3 & & \\
\hline & \multicolumn{5}{|c|}{ Macroporosity (\%) } \\
\hline FO & 27.35 & 30.30 & $28.81 \mathrm{a}$ & 1.15 & 4.0 \\
\hline NTscr & 6.56 & 13.88 & $10.33 \mathrm{c}$ & 2.39 & 23.2 \\
\hline NTcc & 3.86 & 11.56 & $7.07 \mathrm{c}$ & 3.25 & 45.9 \\
\hline NTcs & 5.15 & 12.24 & $8.80 \mathrm{c}$ & 2.65 & 30.1 \\
\hline $\mathrm{CT}$ & 16.5 & 21.27 & $19.54 \mathrm{~b}$ & 1.78 & 9.1 \\
\hline $\mathrm{F}$ test & \multicolumn{5}{|c|}{$10.53^{*}$} \\
\hline $\mathrm{CV}$ & \multicolumn{5}{|c|}{15.8} \\
\hline
\end{tabular}

(1) SD: Standart Deviation. Values followed by the same lowercase letters in the same column are significantly different by the Tukey test $(\mathrm{p}<0.01) ;{ }^{*} \mathrm{p}<0.01$. 

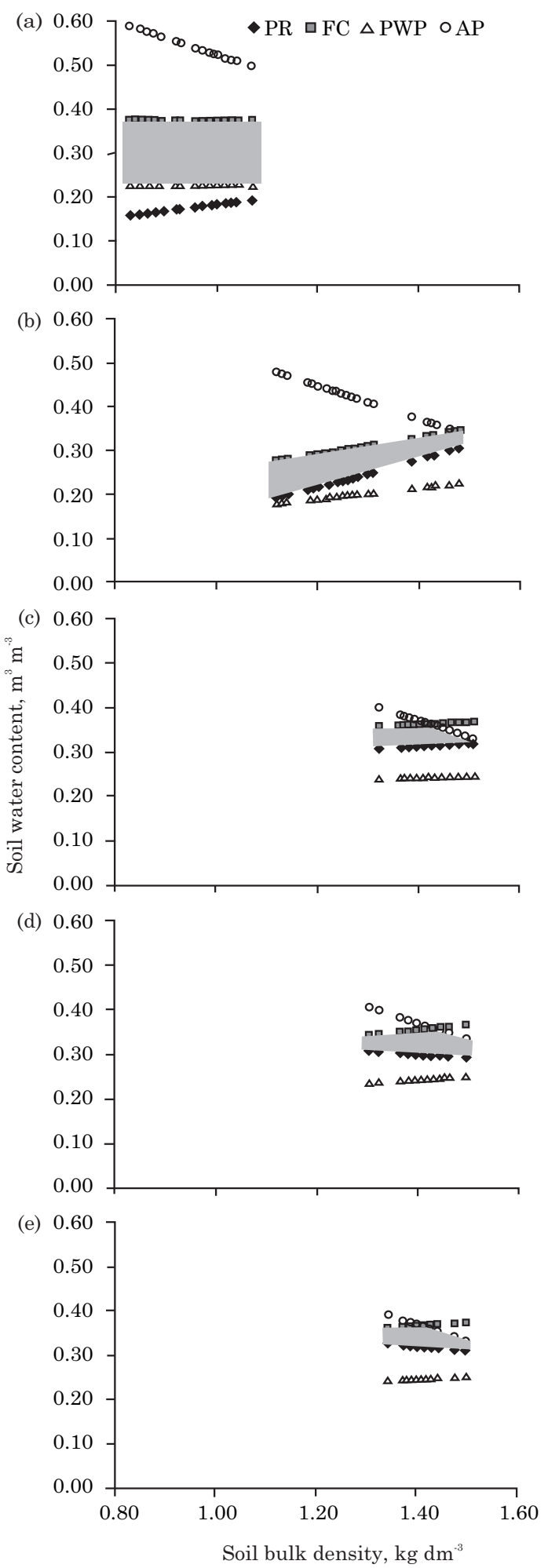

Figure 3. Soil volumetric water content affected by soil bulk density, critical levels of resistance to penetration $(\mathrm{RP}=3.5 \mathrm{MPa})$, field capacity $(\mathrm{FC}=$ $0.01 \mathrm{MPa})$, permanent wilting point $(\mathrm{PWP}=1.5$ $\mathrm{MPa})$, and aeration porosity $(\mathrm{AP}=10 \%)$ in samples from the $0-10 \mathrm{~cm}$ layer of an Oxisol under native forest (a), conventional tillage system (b), and notillage system with soybean/corn rotation (c), continuous corn (d), and continuous soybean (e). al., 1983; Tormena et al., 2007; Blainski et al., 2012). Calonego \& Rosolem (2011) also observed that biopores created by vigorous root systems of cover crops in soil under NT improve the LLWR more than chiseling, and that chiseling is not efficient in increasing the LLWR over a short period of time.

The LLWR upper limit for all management systems was initially the FC. However, AP became the LLWR upper limit for BD values of $1.46 \mathrm{~kg} \mathrm{dm}^{-3}$ for CT, $1.40 \mathrm{~kg} \mathrm{dm}^{-3}$ for NTscr, $1.42 \mathrm{~kg} \mathrm{dm}^{-3}$ for NTcc, and $1.41 \mathrm{~kg} \mathrm{dm}^{-3}$ for NTcs. Under CT, only $7 \%$ of the BD values became AP as the limiting (upper limit) value for the LLWR. In contrast, limiting values of aeration porosity of soil under NT were $62 \%$ for NTscr, $25 \%$ for NTcc, and $50 \%$ for NTcs. The AP was more limiting under NT than under CT because of low soil disturbance (seedbed line) under NT, which increased $\mathrm{BD}$ and reduced TP and MA. Substitution of FC by $\mathrm{AP}$ as the LLWR upper limit is observed in clayey soils because of a low soil MA (Calonego \& Rosolem, 2011). The AP can restrict root growth by reducing the oxygen diffusion rate in soil (Olibone et al., 2010). Substitution of FC by AP as the LLWR upper limit was also observed by Tormena et al. (2007), Calonego \& Rosolem (2011), and Blainski et al. (2012).

The critical values of BD when the LLWR approaches zero were $1.67 \mathrm{~kg} \mathrm{dm}^{-3}$ for $\mathrm{FO}, 1.53 \mathrm{~kg} \mathrm{dm}^{-3}$ for CT, $1.53 \mathrm{~kg} \mathrm{dm}^{-3}$ for NTscr, $1.62 \mathrm{~kg} \mathrm{dm}^{-3}$ for NTcc, and $1.57 \mathrm{~kg} \mathrm{dm}^{-3}$ for NTcs. Under the CT and NT (NTscr, NTcc, and NTcs) systems, as well as under FO, the BD values were not higher than that considered critical for root growth. Thus, it is justifiable to conclude that crop rotation under NT improves soil structural quality as in soil under FO. In contrast, Tormena et al. (2007) reported that crop succession (soybean-wheat) under NT showed low structural stability. The authors also observed that in crop succession (soybean-wheat) and crop rotation (corn-wheat-soybean-oat-soybean-oat) under NT, $18 \%$ of the BD values were higher than that considered critical for root growth $\left(1.30 \mathrm{~kg} \mathrm{dm}^{-3}\right)$. However, a large range of distribution of high BD values $\left(>1.15 \mathrm{~kg} \mathrm{dm}^{-3}\right)$, associated with low LLWR, was observed under crop succession (soybean-wheat) when compared to crop rotation.

\section{CONCLUSIONS}

1. Deforestation and intensification of soil management decreases soil quality by reduction of water stable aggregates and the geometric mean diameter of soil aggregates.

2. The adoption of a no-tillage system improves soil aggregation and its stability.

3. The increase in soil bulk density under the notillage system is not restrictive to root growth as verified by the least limiting water range. 
4. Soil penetration resistance and aeration porosity reduce the least limiting water range of the soil under a no-tillage system and conventional tillage.

5. Continuous corn and continuous soybean as summer crops under no-tillage increase the least limiting water range probably through formation of biopores.

\section{ACKNOWLEDGMENTS}

We are grateful to the CAPES Foundation of the Ministry of Education of Brazil for financial support for this study (Process 8745/11-0), to São Paulo State University - UNESP and The Ohio State University for the exchange program for the first author, and to Felipe Biondi, Priscila Volante, and Tiago Fieno for their help during soil analysis.

\section{LITERATURE CITED}

ALBUQUERQUE, J.A.; REINERT, D.J.; FIORIN, J.E.; RUEDELL, J.; PETRERE, C. \& FONTINELLI, F. Rotação de culturas e sistemas de manejo de solo: Efeito sobre a forma de estrutura do solo ao final de sete anos. R. Bras. Ci. Solo, 19:115-119, 1995

ARAÚJO, M.A.; TORMENA, C.A. \& SILVA, A.P. Propriedades físicas de um Latossolo Vermelho distrófico cultivado e sob mata nativa. R. Bras. Ci. Solo, 28:337-345, 2004.

BAYER, C.; MARTIN-NETO, L.; MIELNICZUK, J.; PAVINATO, A. \& DIECKOW, J. Carbon sequestration in two Brazilian Cerrado soils under no-till. Soil Till. Res., 86:237-245, 2006.

BHATTACHARYYA, R.; TUTI, M.D.; KUNDU, S.; BISHT, J.K. \& BHATT, J.C. Conservation tillage impacts on soil aggregation and carbon pools in a sandy clay loam soil of the Indian Himalayas. Soil Sci. Soc. Am. J., 76:617-627, 2012.

BLAINSKI, E.; TORMENA, C.A.; GUIMARÃES, R.M.L. \& NANNI, M.R. Qualidade física de um Latossolo sob plantio direto influenciada pela cobertura do solo. R. Bras. Ci. Solo, 36:79-87, 2012.

BODDEY, R.M.; JANTALIA, C.P.; CONCEIÇÃO, P.C.; ZANATTA, J.A.; BAYER, C.; MIELNICZUK, J.; DIEKOW, J.; SANTOS, H.P.; DENARDIN, J.E.; AITA, C.; GIACOMINI, S.J.; ALVES, B.J.R. \& URQUIAGA, S. Carbon accumulation at depth in Ferralsols under zero till subtropical agriculture Global Change Biol., 16:784$795,2010$.

CALONEGO, J.C. \& ROSOLEM, C.A. Least limiting water range in soil under crop rotations and chiseling. R. Bras. Ci. Solo, 35:759-771, 2011.

CALONEGO, J.C.; SANTOS, C.H.; TIRITAN, C.S. \& CUNHA JÚNIOR, J.R. Estoques de carbono e propriedades físicas de solos submetidos a diferentes sistemas de manejo. R. Caatinga, 25:128-135, 2012
CARTER, M.R.; ANGERS, D.A. \& TOPP, G.C. Characterizing equilibrium physical condition near the surface of a fine sandy loam under conservation tillage in a humid climate. Soil Sci., 164:101-110, 1999.

CÁSSARO F.A.M.; BORKOWSKI, A.K.; PIRES, L.F.; ROSA, J.A. \& SAAB, S.C. Characterization of a Brazilian clayey soil submitted to conventional and no-tillage management practices using pore size distribution analysis. Soil Till. Res., 111:175-179, 2011.

CAVALIERI, K.M.V.; SILVA, A.P.; TORMENA, C.A.; LEÃO, T.P.; DEXTER, A.R. \& HÅKANSSON, I. Long-term effects of no-tillage on dynamic soil physical properties in a Rhodic Ferrasol in Paraná, Brazil. Soil Till. Res., 103:158. 164, 2009.

CONCEIÇÃO, P.C.; DIEKOW, J. \& BAYER, C. Combined role of no-tillage and cropping systems in soil carbon stocks and stabilization. Soil Till. Res., 129:40-47, 2013.

DANE, J.H. \& HOPMANS, J.W. Pressure plate extractor. In: DANE, J.H. \& TOPP, C., eds. Methods of soil analysis: Physical methods. Madison, Soil Science Society America, 2002. p.688-690.

DON, A.; SCHUMACHER, J. \& FREIBAUER, A. Impact of tropical land-use change on soil organic carbon stocks - a meta-analysis. Global Change Biol., 17:1658-1670, 2011.

DUNGAIT, J.A.J.; HOPKINS, D.W.; GREGORY, A.S. \& WHITMORE, A.P. Soil organic matter turnover is governed by accessibility not recalcitrance. Global Change Biol., 18:1781-1796, 2012.

EHLERS, W.; KÖPKE, U.; HESSE, F. \& BÖHM, W. Penetration resistance and root growth of oats in tilled and untilled loess soil. Soil Till. Res., 3:261-275, 1983.

ELLERT, B.H. \& BETTANY, J.R. Calculation of organic matter and nutrients stored in soils under contrasting management regimes. Can. J. Soil Sci., 75:529-538, 1995.

EMPRESA BRASILEIRA DE PESQUISA AGROPECUÁRIA EMBRAPA. Centro Nacional de Pesquisa de Solos. Sistema brasileiro de classificação de solos. 2.ed. Rio de Janeiro, 2006. 306p.

FAGERIA, N.K. Role of soil organic matter in maintaining sustainability of cropping systems. Commun. Soil. Sci. Plant Anal., 43:2063-2113, 2012.

FIGUEIREDO, G.C.; SILVA, A.P.; TORMENA, C.A.; GIAROLA, N.F.B.; OLIVEIRA, S.O. \& ALMEIDA, B.G. Improvement of a testing apparatus for dynamometry: Procedures for penetrometry and influence of strain rate to quantify the tensile strength of soil aggregates. R. Bras. Ci. Solo, 35:373-387, 2011.

FLINT, L.E. \& FLINT, A.L. Porosity. In: DANE, J.H. \& TOPP, G.C., eds. Methods of soil analysis: Physical methods. Madison, Soil Science Society America, 2002. Part.4, p.241-253.

FUENTES, M.; GOVAERTS, B.; DE LEÓN, F.; HIDALGO, C.; SAYRE, K.D.; ETCHEVERS, J. \& DENDOOVEN, L. Fourteen years of applying zero and conventional tillage, crop rotation and residue management systems and its effect on physical and chemical soil quality. Eur. J. Agron., 30:228-237, 2009 
GOEDERT, W.J. Região dos Cerrados: Potencial agrícola e política para seu desenvolvimento. Pesq. Agropec. Bras., 24:1-17, 1989.

GRABLE, A.R. \& SIEMER, E.G. Effects of bulk density, aggregate size, and soil water suction on oxygen diffusion, redox potentials and elongation of corn roots. Soil Sci. Soc. Am. J., 32:180-186, 1968.

GROSSMAN, R.B., \& REINSCH, T.G. The solid phase, bulk density and linear extensibility. In: DANE, J.H. \& TOPP, G.C., eds. Methods of soil analysis: Physical methods. Madison, Soil Science Society America, 2002. Part 4, p.201228.

HOUGHTON, R.A.; SKOLE, D.L. \& LEFKOWITZ, D.S. Changes in the landscape of Latin America between 1850 and 1985. II - Net release of $\mathrm{CO}_{2}$ to the atmosphere. For. Ecol. Manage., 38:173-199, 1991.

IMHOFF, S.; SILVA, A.P. \& DEXTER, A.R. Factors contributing to the tensile strength and friability of Oxisols. Soil Sci. Soc. Am. J., 66:1656-1661, 2002.

JEMAI, I.; AISSA, N.B.; GUIRAT, S.B.; BEN-HAMMOUDA, M. \& GALLALI, T. Impact of three and seven years of no-tillage on the soil water storage, in the plant root zone, under a dry subhumid Tunisian climate. Soil Till. Res., 126:26-33, 2013.

KEMPER, W.D. \& ROSENAU, R.C. Aggregate stability and size distribution. In: KLUTE, A., eds. Methods of soil analysis: Physical and mineralogical methods. Madison, America Society Agronomy, 1986. p.635-660.

KLEBER, M.; NICO, P.S.; PLANTE, A.F.; FILLEY, T.; KRAMER, M.; SWANSTON, C. \& SOLLINS, P. Old and stable soil organic matter is not necessarily chemically recalcitrant: implications for modeling concepts and temperature sensitivity. Global Change Biol., 17:10971107, 2011.

LAL, R. Soil carbon sequestration impacts on global climate change and food security. Science, 304:1623-1627, 2004.

LAL, R. No-tillage effects on soil properties under different crops in Western Nigeria. Soil Sci. Soc. Am. J., 40:762$768,1976$.

LANZANOVA, M.E.; ELTZ, F.L.F.; NICOLOSO, R.S.; AMADO, T.J.C.; REINERT, D.J. \& ROCHA, M.R. Atributos físicos de um Argissolo em sistemas de culturas de longa duração sob semeadura direta. R. Bras. Ci. Solo, 34:1333-1342, 2010.

LEÃO, T.P. \& SILVA, A.P. A simplified excel algorithm for estimating the least limiting water range of soils. Sci. Agric., 61:649-654, 2004

MARTINS, M.R.; ANGERS, D.A. \& CORÁ, J.E. Carbohydrate composition and water-stable aggregation of an Oxisol as affected by crop sequence under no-till. Soil Sci. Soc. Am. J., 76:475-484, 2012.

NIMMO, J.R. \& PERKINS, K.S. Aggregate stability and size distribution. In: DANE, J.H. \& TOPP, G.C., eds. Methods of soil analysis: Physical methods. Madison, Soil Science Society America, 2002. p.317-328.
OLIBONE, D.; ENCIDE-OLIBONE, A.P. \& ROSOLEM, C.A. Least limiting water range and crop yields as affected by crop rotations and tillage. Soil Use Manage., 26:485493, 2010.

PERES, J.G.; SOUZA, C.F. \& LAVORENTI, N.A. Avaliação dos efeitos da cobertura de palha de cana-de-açúcar na umidade e na perda de água do solo. Eng. Agric., 30:875$886,2010$.

REICHARDT, K. Capacidade de campo. R. Bras. Ci. Solo, 12:211-216, 1988.

REICHERT, J.M.; SUZUKI, L.E.A.S.; REINERT, D.J.; HORN, R. \& HÅKANSSON, I.H. Reference bulk density and critical degree-of-compactness for no-till crop production in subtropical highly weathered soils. Soil Till. Res., 102:242-254, 2009.

ROMANO, N.; HOPMANS, J.W. \& DANE, J.H. Suction table. In: DANE, J.H. \& TOPP, C., eds. Methods of soil analysis: Physical methods. Madison, Soil Science Society America, 2002. p.692-698.

ROSCOE, R. \& BUURMAN, P. Tillage effects on soil organic matter in density fractions of a Cerrado Oxisol. Soil Till. Res., 70:107-119, 2003.

SÁ, J.C.M.; SÉGUY, L.; TIVET, F.; LAL, R.; BOUZINAC, S.; BORSZOWSKEI, P.R.; BRIEDIS, C.; SANTOS, J.B.; HARTMAN, D.C.; BERTOLONI, C.G.; ROSA, J. \& FRIEDRICH, T. Carbon depletion by plowing and its restoration by no till cropping systems in Oxisols of subtropical and tropical agro ecoregions in Brazil. Land Degrad. Develop., 2013.DOI:10.1002/1dr.2218.

SAVAGE, M.J.; RITCHIE, J.T.; BLAND, W.L. \& DUGAS, W.A. Lesser limit of soil water availability. Agron. J., 88:644-651, 1996.

SAS Institute. SAS/STAT User's guide. Version 8.2. Cary, 2001. 943p.

SEBEN JÚNIOR, G.F.; KUHNEN, F.; SYLVESTRE, T.B.; ALMEIDA, C.X. \& CENTURION, J.F. Aggregation of an Ultissol under guava orchard after application of organic guava-processing industry residues. R. Bras. Frutic., 33:1275-1282, 2011.

SILVA, A.P. \& KAY, B.D. Linking process capability analysis and least limiting water range for assessing soil physical quality. Soil Till. Res., 79:167-174, 2004.

SILVA, A.P.; KAY, B.D. \& PERFECT, E. Characterization of the least limiting water range. Soil Sci. Soc. Am. J., 58:1775-1781, 1994.

SIX, J.; FELLER, C.; DENEF, K.; OGLE, S.M.; SÁ, J.C.M. \& ALBRECHT, A. Soil organic matter, biota and aggregation in temperate and tropical soils - Effects of no-tillage. Agronomie, 22:755-775, 2002.

SO, H.B.; GRABSKI, A. \& DESBOROUGH, P. The impact of 14 years of conventional and no-till cultivation on the physical properties and crop yields of a loam soil at Grafton NSW, Australia. Soil Till. Res., 104:180-184, 2009 . 
TIVET, F.; SÁ, J.C.M.; BORSZOWSKEI, P.R.; LETOURMY, P.; BRIEDIS, C.; FERREIRA, A.O.; SANTOS, J.B. \& INAGAKI, T.M. Soil carbon inventory by wet oxidation and dry combustion methods: Effects of land use, soil texture gradients, and sampling depth on the linear model of C-Equivalent correction factor. Soil Sci. Soc. Am. J., 76:1048-1059, 2012.

TORMENA, C.A.; ROLOFF, G. \& SÁ, J.C.M. Propriedades físicas do solo sob plantio direto influenciadas por calagem, preparo inicial e tráfego. R. Bras. Ci. Solo, 22:301-309, 1998.

TORMENA, C.A.; ARAÚJO, M.A.; FIDALSKI, J. \& COSTA, J.M. Variação temporal do intervalo hídrico ótimo de um Latossolo Vermelho distroférrico sob sistemas de plantio direto. R. Bras. Ci. Solo, 31:211-219, 2007.

TORMENA, C.A.; FIDALSKI, J. \& ROSSI JUNIOR, W. Resistência tênsil e friabilidade de um Latossolo sob diferentes sistemas de uso. R. Bras. Ci. Solo, 32:33-42, 2008.

TORMENA, C.A.; BARBOSA, M.C.; COSTA, A.C.S. \& GONÇALVES, A.C.A. Densidade, porosidade e resistência à penetração em Latossolo cultivado sob diferentes sistemas de preparo do solo. Sci. Agríc., 59:795-801, 2002.

van den BERG, M.; KLAMT, E.; van REUWIJK, L.P. \& SOMBROEK, W.G. Pedotransfers functions for the estimation of moisture retention characteristics of Ferralsols and related soils. Geoderma, 78:161-180, 1997.

VEZZANI, F.M. \& MIELNICZUK, J. Agregação e estoque de carbono em Argissolo submetido a diferentes práticas de manejo agrícola. R. Bras. Ci. Solo, 35:213-223, 2011.
VIANA, E.T.; BATISTA, M.A.; TORMENA, C.A.; COSTA, A.C.S. \& INOUE, T.T. Atributos físicos e carbono orgânico em Latossolo Vermelho sob diferentes sistemas de uso e manejo. R. Bras. Ci. Solo, 35:2105-2114, 2011.

WATTS, C.W. \& DEXTER, A.R. Soil friability: Theory, measurement and the effects of management and organic carbon content. Eur. J. Soil Sci., 49:73-84, 1998.

WENDLING, B.; VINHAL-FREITAS, I.C.; OLIVEIRA, R.C.; BABATA, M.M. \& BORGES, E.N. Density, porosity and soil aggregation in areas of cerrado conversion in pine forest, pasture and no-tillage. Biosci. J., 28:256-265, 2012.

WEST, T.O. \& POST, W.M. Soil organic carbon sequestration rates by tillage and crop rotation: A global data analysis. Soil Sci. Soc. Am. J., 66:1930-1946, 2002.

YEOMANS, J.C. \& BREMNER, J.M. A rapid and precise method for routine determination of organic carbon in soil. Commun. Soil Sci. Plant Anal., 19:1467-1476, 1988.

YODER, R.E. A direct method of aggregate analysis of soil and a study of physical nature of soil erosion losses. J. Am. Soc. Agron., 28:337-351, 1936.

ZOTARELLI, L.; ALVES, B.J.R.; URQUIAGA, S.; BODDEY, R.M. \& SIX, J. Impact of tillage and crop rotation on light fraction and intra-aggregate soil organic matter in two Oxisols. Soil Till. Res., 95:196-206, 2007.

ZOTARELLI, L.; ZATORRE, N.P.; BODDEY, R.M.; URQUIAGA, S.; JANTALIA, C.P.; FRANCHINI, J.C. \& ALVES, B.J.R. Influence of no-tillage and frequency of a green manure legume in crop rotations for balancing $\mathrm{N}$ outputs and preserving soil organic C stocks. Field Crops Res., 132:185-195, 2012. 